\title{
Seasonal Changes in Condition Factor and Weight-Length Relationship of Invasive Carassius gibelio (Bloch, 1782) from Leszczynskie Lakeland, Poland
}

\author{
Marcello De Giosa, ${ }^{1}$ Przemyslaw Czerniejewski, ${ }^{2}$ and Agnieszka Rybczyk ${ }^{3}$ \\ ${ }^{1}$ Dipartimento di Matematica, Università degli Studi di Bari, 4 Via Orabona, 70125 Bari, Italy \\ ${ }^{2}$ Department of Fisheries Management in Open Waters, West Pomeranian University of Technology in Szczecin, 4 Ulica Krolewicza, \\ 71-550 Szczecin, Poland \\ ${ }^{3}$ Department of Aquatic Sozology, West Pomeranian University of Technology in Szczecin, 4 Ulica Krolewicza, 71-550 Szczecin, Poland
}

Correspondence should be addressed to Marcello De Giosa; marcello.degiosa@uniba.it

Received 30 July 2014; Revised 3 October 2014; Accepted 10 November 2014; Published 23 November 2014

Academic Editor: Raine Kortet

Copyright (C) 2014 Marcello De Giosa et al. This is an open access article distributed under the Creative Commons Attribution License, which permits unrestricted use, distribution, and reproduction in any medium, provided the original work is properly cited.

Samples of invasive cyprinid fish, the Prussian carp (Carassius gibelio), were collected by fyke nets in Leszczynskie Lakeland (Poland) during the summer and autumn, 2010, and during the spring, 2011. All captured fish were females. For each fish, the total weight $(W, \mathrm{~g})$ and the standard length $(L, \mathrm{~cm})$ were measured and Fulton's condition factor $\left(K_{C}=100 \mathrm{~W} / \mathrm{L}^{3}\right)$ was computed. Graphical investigation and the Mann-Whitney-Wilcoxon test showed statistically significant location shift of the $K_{C}$ distribution from summer to autumn (upward) and from autumn to spring (downward). Relationship between total weight and standard length was described with the mean growth curve $E(W \mid L)=a L^{b}$. Seasonal parameters $(a$ and $b)$ were estimated with a nonlinear regression approach, that is, numerical optimization methods. Growth was allometric in summer and autumn and isometric in spring. The differences between summer and autumn growth curves and between autumn and spring growth curves were statistically significant. The seasonality exhibited by the condition factor and the growth curve may be due to different spawning, breeding, and feeding activity in the different seasons and to variable environmental conditions.

\section{Introduction}

The cyprinid genus Carassius is widespread across Europe and North and East Asia. At least five species are considered: C. carassius (Linnaeus, 1758) in most of Europe and Western Siberia [1], C. langsdorfii (Temminck and Schlegel, 1846) and C. cuvieri (Temminck and Schlegel, 1846) in Japan [2, 3], C. auratus (Linnaeus, 1758) in Mainland East Asia [4], and C. gibelio (Bloch, 1782) in Europe, Siberia, and Northeast Asia $[1,5]$. Some authors recognize additionally the species C. grandoculis and C. buergeri from Japan [6, 7]. In Poland the first documented records of C. gibelio came from 1933, when it was found in ponds northward from Lvov (currently Ukraine) and in southern part of Central Poland. Due to escapes from ponds it appeared in open waters and successively penetrated to next drainages [8]. During the last 20 years it has become more abundant and frequent than native Carassius carassius. Nowadays, it is very common on the whole territory of Poland, particularly numerous in lowland lakes, ponds, and rivers. As a result of lake stocking, C. gibelio began to feature in lake fish landings. In recent years, the total catch in inland waters of Poland was 2090.3 tons, including 81.4 tons of fish from genus Carassius. In Leszczynskie Lakeland, C. gibelio contributed from $42.4 \%$ to $62.1 \%$ to the total weight of fish catch [9]. This fish is turning out to be more and more important in Poland due to its tasty meat and a relatively low price. In addition, on account of its size, the species is an attractive target for anglers.

Condition factor and weight-length relationship are important tools in fish biology, physiology, ecology, fisheries assessment, and conservation [10,11]. Condition factors are used for comparing the condition, fatness, or well-being of fish [12]. Weight-length relationship is needed to estimate growth rate, length and age structures, the average weight at 


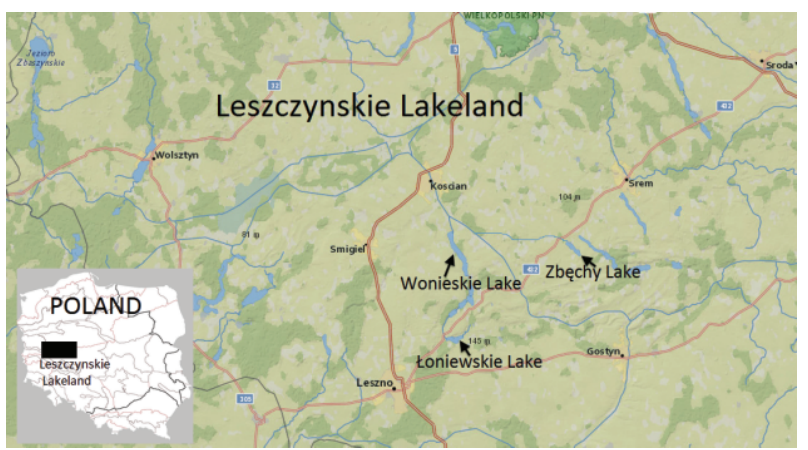

Figure 1: Prussian carps were captured in Wonieskie Lake $\left(52^{\circ} 00^{\prime} 23^{\prime \prime} \mathrm{N} ; 16^{\circ} 54^{\prime} 54^{\prime \prime} \mathrm{E}\right)$, Łoniewskie Lake $\left(52^{\circ} 00^{\prime} 19^{\prime \prime} \mathrm{N} ; 16^{\circ} 41^{\prime} 43^{\prime \prime}\right.$ E) and Zbechy Lake ( $\left.51^{\circ} 53^{\prime} 58^{\prime \prime} \mathrm{N} ; 16^{\circ} 41^{\prime} 37^{\prime \prime} \mathrm{E}\right)$, Leszczynskie Lakeland, Poland.

a given length group, the health status, and other components of fish population dynamic [13-15]. It allows fisheries scientists to convert growth-in-length equations to growth-inweight in stock assessment models [16, 17], estimate biomass from length frequency distributions [18, 19], and compare life history and morphological aspect of population inhabiting different regions [20]. This relationship also enables the computation of condition indexes and allows for comparison of species growth trajectories between sexes and different seasons and regions $[19,21]$.

The available literature contains few reports on C. gibelio. Despite its importance, there is inadequate published information about seasonal changes of condition factor and weight-length relationship of this species.

In this study we investigated seasonality in condition factor and weight-length relationship of invasive C. gibelio from three connected lakes of Leszczynskie Lakeland (West Poland): Wonieskie Lake, Łoniewskie Lake, and Zbechy Lake. The sampling sites and the three lakes were in the same hydrological and environmental condition. The lakes are connected by rivers and canals. The fish move in whole lake and even migrate from lake to lake. We did not expect differences in the fish population characteristics from one sampling site or lake to another. The study question was instead if they showed seasonal variation. Since the condition factor and the weight-length relationship for fish may be conditioned by spawning, breeding, and feeding activity as well as by environmental conditions, we hypothesized that these peculiarities of Prussian carps in Leszczynskie Lakeland change seasonally.

\section{Material and Methods}

2.1. Sampling and Measurements. The Prussian carps were captured by fyke nets during summer and autumn 2010 and spring 2011 in Wonieskie Lake $\left(52^{\circ} 00^{\prime} 23^{\prime \prime} \mathrm{N} ; 16^{\circ} 54^{\prime} 54^{\prime \prime} \mathrm{E}\right)$, Łoniewskie Lake $\left(52^{\circ} 00^{\prime} 19^{\prime \prime} \mathrm{N} ; 16^{\circ} 41^{\prime} 43^{\prime \prime} \mathrm{E}\right)$, and Zbechy Lake $\left(51^{\circ} 53^{\prime} 58^{\prime \prime} \mathrm{N} ; 16^{\circ} 41^{\prime} 37^{\prime \prime} \mathrm{E}\right)$, Leszczynskie Lakeland, Poland (see Figure 1).

The fish were caught in similar proportions from each lake and for each season.
The characteristics of the fyke nets were mesh size $=$ $20 \mathrm{~mm}$ (knot-to-knot), leader length $=6 \mathrm{~m}$, total length $=$ $9 \mathrm{~m}$, height $=70 \mathrm{~cm}$ (at first ring), and 1 funnel throat.

Fyke nets were set in the morning in 4 sample sites in the coastal part of each lake, at a depth of $2 \mathrm{~m}$. Distance between sample sites was around $50 \mathrm{~m}$. The nets were raised after 72 hours. The raising time periods were July 12th to 14th and 19th to 21th, 2010 (summer), November 22th to 24th and December 1th to 3th, 2010 (autumn), March 29th to 31th and April 5th to 7th, 2011 (spring). Each one of the previous threeday periods was composed of one raising day for each lake in the following order: Wonieskie, Łoniewskie, Zbechy.

The sample sizes for season were summer $=105$, autumn $=110$, and spring $=96$.

All captured and analysed C. gibelio in this study were females.

For each fish, the total weight $(W, \mathrm{~g})$ and the standard length $(L, \mathrm{~cm})$ were measured, respectively, by Axis Electronics scales to the nearest $0.1 \mathrm{~g}$ and by electronic Vernier caliper to the nearest $\mathrm{mm}$.

2.2. Statistical Methods. We started with a graphical data exploration process. Dotplots, boxplots, and bivariate scatter plots were used to detect outliers and gain preliminary insights about seasonal data distributions and relationships [22]. Fulton's condition factor, $K_{C}=100 \mathrm{~W} / \mathrm{L}^{3}$ [23], was calculated for all individuals. Preliminary statistics (mean and standard deviation) were computed seasonably for $W, L$, and $K_{C}$. Conditional boxplots were used to gain insight about the seasonal variation of the condition factor. The MannWhitney-Wilcoxon test was used to evaluate statistical significance of seasonal shift of the distribution of $K_{C}$. Relationship between $W$ and $L$ was described with the nonlinear regression model $W=a L^{b}+\varepsilon$, with mean growth curve $E(W \mid L)=a L^{b}$, characterized by the intercept $a$ and the growth parameter $b$, and normal error $\varepsilon \sim N\left(0, s^{2}\right)$. The model was fitted to data, for each season, with a nonlinear regression approach. That is, the minimization of the residual sum of squares was reached by numerical iterative optimization procedures. The GaussNewton algorithm was applied at each step. It relies on linear approximations to the nonlinear (with respect to $b$ ) mean function $E(W \mid L)$ [24]. Graphical procedures (residual plots) were used to check and validate the assumptions underlying our model: correct mean function, variance homogeneity, normality, and independence with respect to sampling sites and lakes and with respect to sampling time in each season [25].

Wald 95\% confidence intervals for $b$ were also computed for each season. For $b$ (and similarly for $a$ ) they are defined as $\widehat{b} \pm t(0.975, n-2) \operatorname{se}(\widehat{b})$, where $\widehat{b}$ is the seasonal estimate of $b$, se $(\widehat{b})$ is the estimated asymptotic standard error of $\widehat{b}$, $t(0.975, n-2)$ is the percentile of a $t$-distribution with $n-2$ degrees of freedom, and $n$ is the number of observations [25]. Confidence intervals were also used to test for isometry or allometry of growth in each season. That is, the isometry null hypothesis $(H 0: b=3)$ was rejected at the $5 \%$ significance level if the $95 \%$ confidence interval for $b$ did not contain the value 3 . 
TABLE 1: Seasonal summary statistics for standard length $(L)$, total weight $(W)$, and Fulton's condition factor $\left(K_{C}\right)$ of Prussian carps from Leszczynskie Lakeland, Poland. Values are minimum, maximum, and sample mean \pm standard deviation.

\begin{tabular}{lccr}
\hline Season & $L, \mathrm{~cm}$ & $W, \mathrm{~g}$ & $K_{C}, \mathrm{~g} \cdot \mathrm{cm}^{-3}$ \\
\hline Summer $(n=104)$ & $20.4,30.0,25.6 \pm 1.9$ & $325,920,612.6 \pm 127.6$ & $2.8,4.6,3.6 \pm 0.4$ \\
Autumn $(n=110)$ & $19.4,34.4,25.8 \pm 2.9$ & $280,1540,717.7 \pm 248.0$ & $3.2,5.4,4.1 \pm 0.4$ \\
Spring $(n=94)$ & $21.3,34.5,26.6 \pm 3.0$ & $320,1620,740.3 \pm 280.5$ & $2.8,4.4,3.7 \pm 0.3$ \\
\hline
\end{tabular}

Statistical significance of the difference between the growth curves related to subsequent seasons was evaluated comparing, with an $F$-test, two nested models: Model A, with different parameters between seasons, and Model B, with the same parameters for both seasons. Model B is a submodel of Model A. The $F$-test statistic is defined as

$$
F=\frac{\left(\mathrm{RSS}_{\mathrm{B}}-\mathrm{RSS}_{\mathrm{A}}\right) /\left(\mathrm{df}_{\mathrm{B}}-\mathrm{df}_{\mathrm{A}}\right)}{\mathrm{RSS}_{\mathrm{A}} / \mathrm{df}_{\mathrm{A}}},
$$

where RSS stays for Residuals Sum of Squares, df stays for degrees of freedom, and subscripts A and B refer to Model A and Model B, respectively. A large F-value means a large improvement in the fit when considering Model A instead of Model B, that is, considering two different seasonal growth curves instead of a single one. The $P$ value was obtained from an $F$-distribution with degree of freedom $\left(\mathrm{df}_{\mathrm{B}}-\mathrm{df}_{\mathrm{A}}, \mathrm{df}_{\mathrm{A}}\right)$. The method is also called the extra-sum-of-squares $F$-test [26].

All graphs and statistical analysis in this paper were produced using the software package R [27].

\section{Results}

All captured fish were unisexual female.

In the preliminary graphical data exploration process (not shown here), few outliers were detected and removed from the data set. In the final sample, the number of individuals for each season was summer $=104$, autumn $=110$, and spring $=$ 94. In Table 1, the minimum, maximum, and sample mean \pm standard deviation for $L, W$, and $K_{C}$ are presented for each season.

The conditional boxplots for $K_{C}$, shown in Figure 2, exhibited a clear seasonal variability, with its maximum in autumn and its minimum in summer.

The Mann-Whitney-Wilcoxon test showed that the upward shift, from summer to autumn, of the $K_{C}$ distribution was statistically significant (MWW-value $=2191, P$ value $<0.001$, based on normal approximation). The downward shift from autumn to spring was also statistically significant $(\mathrm{MWW}$-value $=7536, P$ value $<0.001$, based on normal approximation).

Figure 3 shows the conditional scatter plot of $W$ versus $L$ for each season.

Estimates and Wald's $95 \%$ confidence intervals for parameters $a$ and $b$, for each season, are shown in Table 2. In summer and autumn, growth was allometric ( $\mathrm{HO}: b=3$ rejected at the 0.05 significance level). In spring, growth was isometric ( $H 0: b=3$ not rejected at the 0.05 significance level).

Residual plots did not show any evident departure from model assumptions.
TABLE 2: Seasonal growth curve parameters $a$ and $b$ for Prussian carps from Leszczynskie Lakeland, Poland. Values are estimates (bold) and Wald's 95\% confidence intervals in a nonlinear regression model.

\begin{tabular}{lcc}
\hline Season & $a$ & $b$ \\
\hline Summer & $\mathbf{0 . 1 5 2}(0.022,0.282)$ & $\mathbf{2 . 5 5 5}(2.294,2.816)$ \\
Autumn & $\mathbf{0 . 0 7 4}(0.032,0.116)$ & $\mathbf{2 . 8 1 6}(2.645,2.987)$ \\
Spring & $\mathbf{0 . 0 2 9}(0.017,0.041)$ & $\mathbf{3 . 0 7 8}(2.953,3.203)$ \\
\hline
\end{tabular}

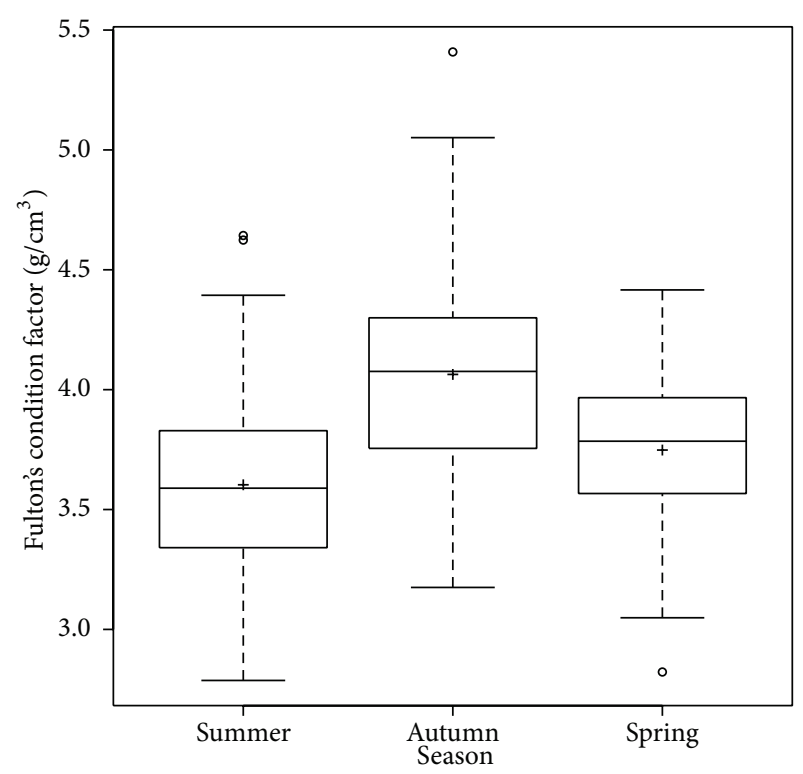

FIGURE 2: Seasonal variation of average Fulton's condition factor $\left(K_{C}\right)$ of Prussian carp, Carassius gibelio, in Leszczynskie Lakeland, Poland. Rectangular part of the plot extends from lower to the upper quartile; centerline within each box show location of sample median and cross location of sample mean. Circles indicate (not extreme) outliers.

Difference between the summer and the autumn growth curves (see Figure 4$)$ was statistically significant $(F$-value $=$ 46.585 , $\mathrm{df}=(212,210)$, and $P$ value $<0.001)$. Difference between the autumn and spring growth curves (see Figure 5) was also statistically significant $(F$-value $=14.078, \mathrm{df}=$ $(202,200)$, and $P$ value $<0.001)$.

\section{Discussion}

The Prussian carp, Carassius gibelio, represents an interesting and unique species in which the coexistence of gynogenetic 


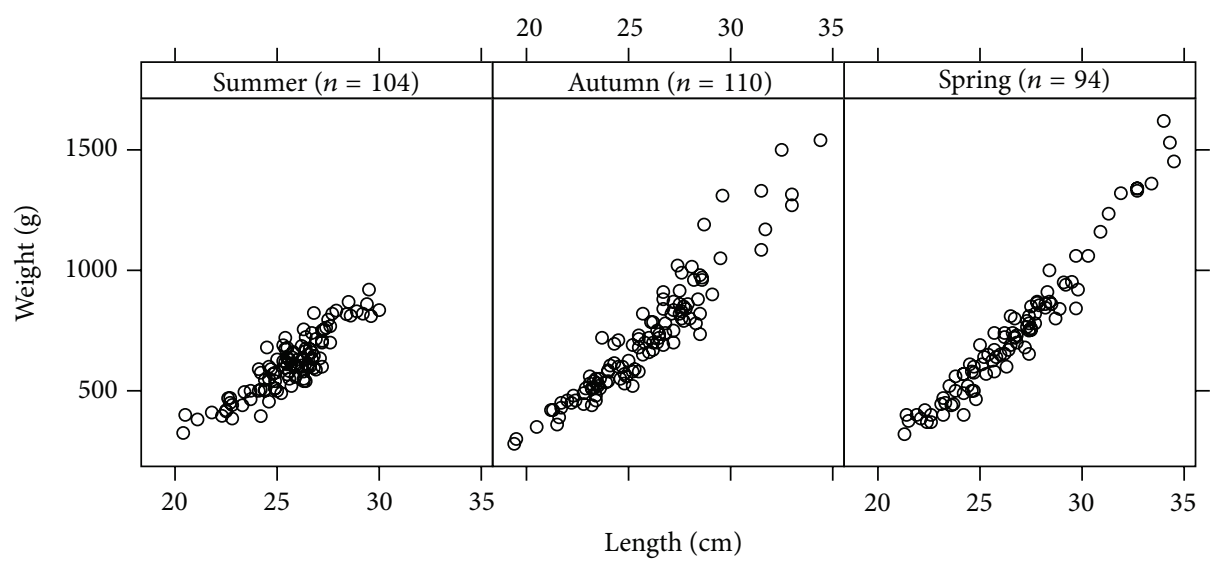

FIGURe 3: Scatter plot of Weight $(\mathrm{g})$ versus Length $(\mathrm{cm})$ of Prussian carps in Leszczynskie Lakeland, Poland, conditional on season.

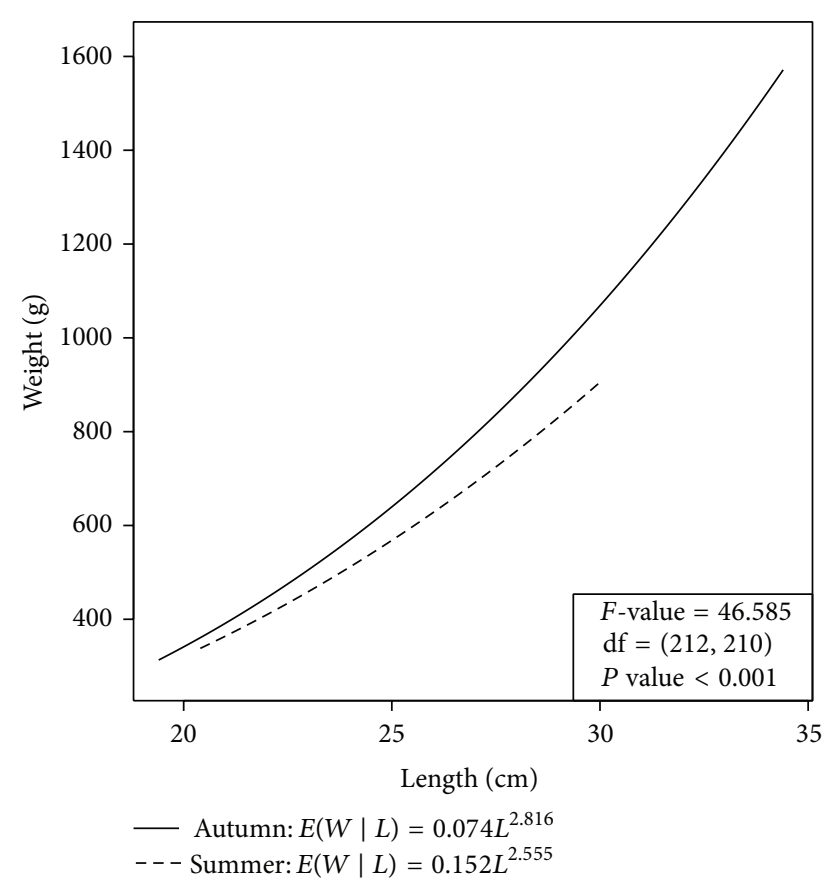

FIGURE 4: Graphical comparison of the growth curves $E(W \mid L)=$ $a L^{b}$ fitted to autumn data and to summer data. $F$-value $=\left(\left(\mathrm{RSS}_{\mathrm{B}}-\right.\right.$ $\left.\left.\mathrm{RSS}_{\mathrm{A}}\right) /\left(\mathrm{df}_{\mathrm{B}}-\mathrm{df}_{\mathrm{A}}\right)\right) /\left(\mathrm{RSS}_{\mathrm{A}} / \mathrm{df}_{\mathrm{A}}\right)$, where subscripts $\mathrm{A}$ and $\mathrm{B}$ refer to a model with different parameters between seasons and a model with the same parameter for both season, respectively; $P$-value obtained from an $F$-distribution with degree of freedom $\left(\mathrm{df}_{\mathrm{B}}-\mathrm{df}_{\mathrm{A}} ; \mathrm{df}_{\mathrm{A}}\right)[26]$.

reproduction and gonochoristic reproduction is known. The majority of the European populations of this species have been considered unisexual, consisting of triploid females reproducing by gynogenesis [28]. In Leszczynskie Lakeland, all caught fish were unisexual female. All the eggs of the triploid Prussian carps developed gynogenetically into females when stimulated by sperm from other species.

Usually, in deep lakes, fish migrate because of diet or reproductive needs, although in some cases the reason for migration remains unknown [29]. Wonieskie, Łoniewskie,

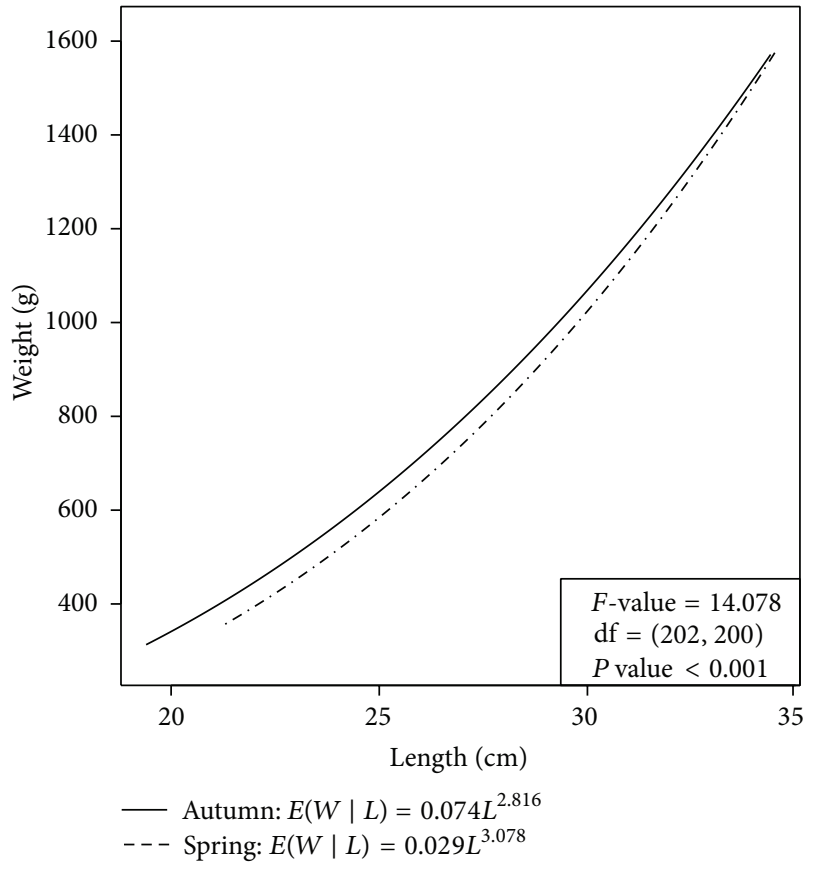

FIgURE 5: Graphical comparison of the growth curves $E(W \mid L)=$ $a L^{b}$ fitted to autumn data and to spring data. $F$-value $=\left(\left(\mathrm{RSS}_{\mathrm{B}}-\right.\right.$ $\left.\left.\mathrm{RSS}_{\mathrm{A}}\right) /\left(\mathrm{df}_{\mathrm{B}}-\mathrm{df}_{\mathrm{A}}\right)\right) /\left(\mathrm{RSS}_{\mathrm{A}} / \mathrm{df}_{\mathrm{A}}\right)$, where subscripts $\mathrm{A}$ and $\mathrm{B}$ refer to a model with different parameters between seasons and a model with the same parameter for both season, respectively; $P$-value obtained from an F-distribution with degree of freedom $\left(\mathrm{df}_{\mathrm{B}}-\mathrm{df}_{\mathrm{A}} ; \mathrm{df}_{\mathrm{A}}\right)$ [26].

and Zbechy are shallow lakes. In most of each lake depth does not exceed $3 \mathrm{~m}$. The maximum depth is less than $9 \mathrm{~m}$. Prussian carps migrate to lake surface when looking for food. In the breeding season these fish migrate to shallow shores with aquatic plants (at a depth of about 1-2 m) for spawning. In winter all fish move to deeper warmer water. Like in other lakes [30], fish overwinter in an inactive state and avoid freezing by burrowing into the warmer mud at the lake bottom. In summer we captured fish leaving the breeding place after spawning. In autumn we captured fish after an 
intensive feeding activity. In spring we captured fish that had gone through a hard and cold period.

The condition factor and the weight-length relationship have got significant role in fishery management. In this paper we showed that the mean condition factor of Carassius gibelio from Leszczynskie Lakeland exhibits a clear seasonal variability. This is in accordance with other published results on unisexual female population [31], bisexual populations of Prussian carp [32, 33], and other species of fish [23].

In Poland, Prussian carp reproduction begins at the end of May, when water temperature is about $18-19^{\circ} \mathrm{C}$ [5]. For Carassius gibelio, the minimum $K_{C}$ values were recorded after spawning had just occurred, mainly in the triploid gynogenetic females [31], which dominated in European lakes. In summer, after the breeding season, we found fish in the worse condition, because most of them were spawned. Spawning is a physically demanding and stressful period, which can affect also immune function [34, 35]. Cyprinid fish reach the highest values of immune variables including respiratory burst, leukocyte count, and leukocrit in spawning period [36]. High number of leucocytes, especially granulocytes, is a common consequence of infection and it may play an important role on fish condition.

However, since in summer water temperature is optimal for growing and the greatest feeding activity starts [30, 37], the condition of Prussian carps increased reaching the highest value in autumn. This is due to fats deposition during the preceding growing season [21].

Winter temperatures of Polish lakes are very low, usually below the freezing point of water. In that season, Prussian carps enter into a phase of anabiosis by radically altering metabolism and consuming all the energy stored during the previous warmer period. In this period condition got worse. After winter, in spring, Prussian carps were back in poor condition. The same results were found in [38].

The condition values of Carassius gibelio from Leszczynskie Lakeland were higher than other published values from some European waters [39, 40], Turkey [32, 41, 42], and Iran [43]. This may be due to the fact that the three lakes considered are all eutrophic. There are a lot of aquatic plants, mainly: Phragmites australis, Acorus calamus, Canadian waterweed, Hornwort, and Nymphaeids. The composition of the bottom substrate in all sites was sand $=60 \%$, organic matter $=10 \%$, and lake mud $=30 \%$. This is a very good feeding habitat for fish, because usually distribution of diet resources for fish is influenced by presence of aquatic plants. According to [44], macroinvertebrate biomass is higher in aquatic plants than in unstructured open water habitat. The presence of larger areas of colonisable substrates and the refuge effect of the aquatic plants in the considered lakes makes the complex habitat generally more favourable for the benthic fauna [45]. It should be noted that bottom fauna has a main role in diet of C. gibelio.

Seasonality is also very important in structuring the isometry or allometry of a fish species because the weight-length relationship is largely determined by seasonally oscillating natural factors such as diet, habitat, reproductive activity, and stress [21].

For Carassius gibelio, some authors reported value of the growth parameter $b$ ranging from 2.1 to 3.3 [41, 42, 46].
According to [31, 46] the fish showed positive allometric growth $(b>3)$ in some lakes but in others isometric growth $(b=3)$. We found that $b$ values ranged between 2.555 and 3.078 in C. gibelio and differ between seasons. Difference between the summer growth curve and the autumn growth curve was statistically significant as well as the difference between the autumn and spring growth curves. Our results agree with earlier report [12] which stated that season might influence the weight-length relationship. In [46], for example, the authors found that the $b$ value recorded in the winter was significantly lower than 3 indicating hypoallometric growth. In other seasons average $b$ slightly deviated from isometric growth. Our studies showed allometric growth in summer and autumn and isometric growth in spring. There has been continuous debate on the impact of seasons on the weightlength relationship in fish and majority of fish biologists believe that $b$ values depend on physiological growth condition such as gonad development or food availability [47], biological and environmental condition, and geographical, temporal, and sampling factor [21, 48].

Note that, with $K_{C}=100 \mathrm{~W} / \mathrm{L}^{3}$ and $E(W \mid L)=a L^{b}$, $E\left(K_{C} \mid L\right)=100 a L^{b-3}$. It follows that the mean condition factor does not depend on $L$ if growth is isometric $(b=$ 3 ) and decreases with $L$ (that is, small fish have a better condition than big fish) if growth is hypoallometric $(b<3)$. Concerning the $K_{C}-L$ relationship there are contradictory published results in the literature. In [41] the authors pointed out that the mean condition factor of the Crucian carps in age group I (at mean fork length $11.3 \mathrm{~cm}$ ) was $2.239 \mathrm{~g} / \mathrm{cm}^{3}$ and in age group VI (mean fork length $29.6 \mathrm{~cm}$ ) was higher: $3.326 \mathrm{~g} / \mathrm{cm}^{3}$. According to [46], in the Dal Lake, and [31], in the Chimaditis Lake, fish of different size showed no difference in condition; that is, small specimens had the same condition as large specimens. In [49] the authors conducted studies on the biological aspects of fish in Manasbal Lake and found that, for the Crucian carp (C. carassius), $b=2.47$, so that the condition factor decreased with length.

Our results showed no differences in condition between small and large specimens only in spring. In summer and autumn the condition factor decreased with length. Hypoallometric growth in the summer sample may indicate that bigger fish were sexually mature and spawned and had a decreased condition factor compared to their smaller and immature counterparts. However, we point out that the lack of bigger sized specimens may have influenced $K_{C}$ values in summer.

\section{Conclusion}

Our results showed that the condition factor and the weightlength relationship of Prussian carp varies according to season; that is, it is influenced by environmental conditions. In Leszczynskie Lakeland, the lowest condition values were in summer, after spawning season, and the highest were in autumn, after fish have deposited fat for the coming cold season. Furthermore, seasonality of condition factor could be attributed to low feeding intensity and degeneration of ovaries during winter. The value obtained in this study 
showed that specimens from Leszczynskie Lakeland were in better condition than some other populations from European and Asian waters. This may be due to environmental differences between lakes.

The seasonal changes, notably in the period during and immediately after spawning, affect the weight-length relationship in Prussian carps. Values of the growth parameter in the weight-length relationship imply hypoallometric growth in summer and autumn; that is, the increase in weight is not faster than the cube of the increase in length. In these seasons small specimens are in better condition than bigger ones. Probably, hypoallometric growth may indicate that bigger fish were sexually mature and spawned. study.

Our hypotheses were confirmed by the results of this

\section{Conflict of Interests}

The authors declare that there is no conflict of interests regarding the publication of this paper.

\section{References}

[1] M. Kottelat and J. Freyhof, Handbook of European Freshwater Fishes, Publications Kottelat, Cornol, Switzerland, 2007.

[2] K. Hosoya, "Cyprinidae," in Fishes of Japan with Pictorial Keys to the Species, T. Nakabo, Ed., pp. 253-272, Tokai University Press, Tokyo, Japan, 2002.

[3] G. Yamamoto, M. Takada, K. Iguchi, and M. Nishida, "Genetic constitution and phylogenetic relationships of Japanese crucian carps (Carassius)," Ichthyological Research, vol. 57, no. 3, pp. 215222, 2010.

[4] K. Rylková, L. Kalous, V. Šlechtová, and J. Bohlen, "Many branches, one root: first evidence for a monophyly of the morphologically highly diverse goldfish (Carassius auratus)," Aquaculture, vol. 302, no. 1-2, pp. 36-41, 2010.

[5] J. A. Szczerbowski, “Carassius auratus (Linneaus 1978)," in The Freshwater Fishes of Europe, Volume 5/III: Cyprinidae 2, Part III: Carassius, Cyprinus, Gasterosteidae, P. M. Banarescu and H. J. Paepke, Eds., pp. 5-41, Aula-Verlag, Wiebelsheim, Germany, 1978.

[6] H. Kawanabe and N. Mizuno, Freshwater Fishes of Japan, YamaKei, Tokyo, Japan, 1989, (Japanese).

[7] T. Suzuki, H. Nagano, T. Kobayashi, and K. Ueno, "Morphological characteristics of Nigorobuna Carassius auratus grandoculis called Io in Lake Nishino," Fisheries Science, vol. 71, no. 3, pp. 679-681, 2005.

[8] J. Grabowska, J. Kotusz, and A. Witkowski, "Alien invasive fish species in Polish waters: an overview," Folia Zoologica, vol. 59, no. 1, pp. 73-85, 2010.

[9] A. Wolos, H. Draszkiewicz-Mioduszewska, and M. Mickiewicz, "Characteristics of inland fisheries management in 2013," in Sustainable Use of Fisheriey Resources in Background of Their State in 2013, M. Mickiewicz and A. Wolos, Eds., Inland Fisheries Institute, Olsztyn, Poland, 2014.

[10] R. Froese, "Length-weight relationships for 18 less-studied fish species," Journal of Applied Ichthyology, vol. 14, pp. 117-118, 1998.

[11] J. Oscoz, F. Campos, and M. C. Escala, "Weight-length relationships of some fish species of the Iberian Peninsula," Journal of Applied Ichthyology, vol. 21, no. 1, pp. 73-74, 2005.
[12] F. W. Tesch, "Age and growth," in Fish Production in Fresh Waters, W. E. Ricker, Ed., pp. 98-130, Blackwell, Oxford, UK, 1971.

[13] J. E. Beyer, "On length-weight relationship. Computing the mean weight of the fish of a given length class," FishByte, vol. 5, pp. 11-13, 1987.

[14] T. Bolger and P. L. Connolly, "The selection of suitable indices for the measurement and analysis of fish condition," Journal of Fish Biology, vol. 34, no. 2, pp. 171-182, 1989.

[15] N. E. Kohler, J. G. Casey, and P. A. Turner, "Length-weight relationships for 13 species of sharks from the western North Atlantic," Fishery Bulletin, vol. 93, no. 2, pp. 412-418, 1995.

[16] T. Morato, P. Afonso, P. Lourinho, J. P. Barreiros, R. S. Santos, and R. D. M. Nash, "Length-weight relationships for 21 coastal fish species of the Azores, north-eastern atlantic," Fisheries Research, vol. 50, no. 3, pp. 297-302, 2001.

[17] D. K. Moutopoulos and K. I. Stergiou, "Length-weight and length-length relationships of fish species from the Aegean Sea (Greece)," Journal of Applied Ichthyology, vol. 18, no. 3, pp. 200203, 2002.

[18] J. Dulcic and M. Kraljevic, "Weight-length relationships for 40 in the Eastern Adriatic (Croatian waters)," Fisheries Research, vol. 21, pp. 243-251, 1996.

[19] G. Petrakis and K. I. Stergiou, "Weight-length relationships for 33 fish species in Greek waters," Fisheries Research, vol. 21, no. 3-4, pp. 465-469, 1995.

[20] K. I. Stergiou and D. K. Moutopoulos, "A review of lengthweight relationships of fishes from Greek marine waters," Naga, The ICLARM Quarterly, vol. 24, no. 1-2, pp. 23-39, 2001.

[21] R. Froese, "Cube law, condition factor and weight-length relationships: history, meta-analysis and recommendations," Journal of Applied Ichthyology, vol. 22, no. 4, pp. 241-253, 2006.

[22] A. F. Zuur, E. N. Ieno, and C. S. Elphick, "A protocol for data exploration to avoiding common statistical problems," Methods in Ecology and Evolution, vol. 1, pp. 3-14, 2010.

[23] E. D. Le Cren, “The length-weight relationship and seasonal cycle in gonad weight and condition in the perch (Perca fluviatilis)," Journal of Animal Ecology, vol. 20, pp. 201-219, 1951.

[24] D. M. Bates and D. G. Watts, Nonlinear Regression Analysis and Its Applications, John Wiley \& Sons, New York, NY, USA, 1988.

[25] C. Ritz and J. C. Streibig, Nonlinear Regression with R, Springer, Berlin, Germany, 2008.

[26] H. J. Mothulsky and A. Christopoulos, Fitting Models to Biological Data Using Linear and Nonlinear Regression: A Practical Guide to Curve Fitting, Oxford University Press, Oxford, UK, 2004.

[27] R Core Team, R: A Language and Environment for Statistical Computing, R Foundation for Statistical Computing, Vienna, Austria, 2013, http://www.R-project.org/.

[28] B. Tóth, E. Várkonyi, A. Hidas, E. Meleg, and L. Váradi, "Genetic analysis of offspring from intra- and interspecific crosses of Carassius auratus gibelio by chromosome and RAPD analysis," Journal of Fish Biology, vol. 66, no. 3, pp. 784-797, 2005.

[29] M. Lucas and E. Baras, Migration of Freshwater Fishes, Blackwell Science, Malden, Mass, USA, 2001.

[30] O.-P. Penttinen and I. J. Holopainen, "Seasonal feeding activity and ontogenetic dietary shifts in crucian carp, Carassius carassius," Environmental Biology of Fishes, vol. 33, no. 1-2, pp. 215221, 1992. 
[31] I. D. Leonardos, A. C. Tsikliras, V. Eleftheriou et al., "Life history characteristics of an invasive cyprinid fish (Carassius gibelio) in Chimaditis Lake (northern Greece)," Journal of Applied Ichthyology, vol. 24, no. 2, pp. 213-217, 2008.

[32] Ş. G. Kirankaya and F. G. Ekmekçi, "Life-history traits of the invasive population of Prussian carp, Carassius gibelio (Actinopterigi: Cypriniformes: Cyprinidae), from Gelingüllü reservoir, Yozgat, Turkey," Acta Ichthyologica et Piscatoria, vol. 43, no. 1, pp. 31-40, 2013.

[33] M. Tsoumani, R. Liasko, P. Moutsaki, I. Kagalou, and I. Leonardos, "Length-weight relationships of an invasive cyprinid fish (Carassius gibelio) from 12 Greek lakes in relation to their trophic states," Journal of Applied Ichthyology, vol. 22, no. 4, pp. 281-284, 2006.

[34] C. B. Schreck, "Stress and compensation in teleostean fishes: response to social and physical factors," in Stress and Fish, A. D. Pickering, Ed., pp. 295-321, Academic Press, London, UK, 1981.

[35] R. Kortet, J. Taskinen, T. Sinisalo, and I. Jokinen, "Breedingrelated seasonal changes in immunocompetence, health state and condition of the cyprinid fish, Rutilus rutilus, L," Biological Journal of the Linnean Society, vol. 78, no. 1, pp. 117-127, 2003.

[36] K. Rohlenová and A. Šimková, "Are the immunocompetence and the presence of metazoan parasites in cyprinid fish affected by reproductive efforts of cyprinid fish?" Journal of Biomedicine and Biotechnology, vol. 2010, Article ID 418382, 14 pages, 2010.

[37] I. J. Holopainen, W. M. Tonn, and C. A. Paszkowski, “Tales of two fish: The dichotomous biology of crucian carp (Carassius carassius (L.)) in northern Europe," Annales Zoologici Fennici, vol. 34, no. 1, pp. 1-22, 1997.

[38] G. Radtke, "Comparison of seasonal activity of the lake minnow, Eupallasella percnurus (Pall.), and crucian carp, Carassius carassius (L.), in small water bodies in northern Poland," Archives of Polish Fisheries, vol. 19, no. 3, pp. 175-182, 2011.

[39] J. A. Szczerbowski and A. Szczerbowski, Karasie [The genus Carassius], pp. 45-88, Instytut Rybactwa Śródlądowego w Olsztynie, 1996, (Polish).

[40] T. Treer, D. Matulić, G. Bogdanović et al., "The condition of allochtonous fishes in the Mediterranean Vransko Lake," Journal of Applied Ichthyology, vol. 27, no. 3, pp. 965-967, 2011.

[41] I. Balik, R. Özkök, H. Çubuk, and R. Uysal, "Investigation of some biological characteristics of the silver crucian carp, Carassius gibelio (Bloch 1782) population in Lake Eǧirdir," Turkish Journal of Zoology, vol. 28, no. 1, pp. 19-28, 2004.

[42] S. Bulut, R. Mert, B. Algan, M. Özbek, B. Ünal, and M. Konuk, "Several growth characteristics of an invasive," Notulae Scientia Biologicae, vol. 5, no. 2, pp. 133-138, 2013.

[43] G. Moradinasab, M. Daliri, R. Ghorbani, S. Y. Paighambari, and R. Davoodi, "Length-weight and length-length relationships, relative condition factor and Fulton's condition factor of five Cyprinid species in Anzali wetland, southwest of the Caspian Sea," Caspian Journal of Environmental Sciences, vol. 1, no. 10, pp. 25-31, 2012.

[44] A. Hargeby, G. Andersson, I. Blindow, and S. Johansson, "Trophic web structure in a shallow eutrophic lake during a dominance shift from phytoplankton to submerged macrophytes," Hydrobiologia, vol. 279-280, no. 1, pp. 83-90, 1994.

[45] R. E. Brock, "An experimental study on the effects of grazing by parrotfishes and role of refuges in benthic community structure," Marine Biology, vol. 51, no. 4, pp. 381-388, 1979.

[46] U. R. Zargar, A. R. Yousuf, B. Mushtaq, and D. Jan, "Lengthweight relationship of the crucian carp, Carassius carassius in relation to water quality, sex and season in some lentic water bodies of Kashmir Himalayas," Turkish Journal of Fisheries and Aquatic Sciences, vol. 12, no. 3, pp. 685-691, 2012.

[47] S. Jennings, M. J. Kaiser, and J. D. Reynolds, Marine Fisheries Ecology, Blackwell Science, London, UK, 2001.

[48] T. B. Begenal and F. W. Tesch, "Age and growth," in Methods for Assessment of Fish Production in Fresh Waters, T. B. Begenal, Ed., vol. 3 of IBP Handbook, pp. 101-136, Blackwell Science Publications, Oxford, UK, 1978

[49] A. R. Yousuf, G. Firdus, M. H. Balkhi, and A. K. Pandit, "Studies on the length-weight relationship in some cyprinid fishes," in Current Trends in Fish and Fishery Biology and Aquatic Ecology, A. R. Yousuf, M. K. Raina, and M. Y. Qadri, Eds., pp. 199-206, University of Kashmir, Kashmir, India, 1992. 

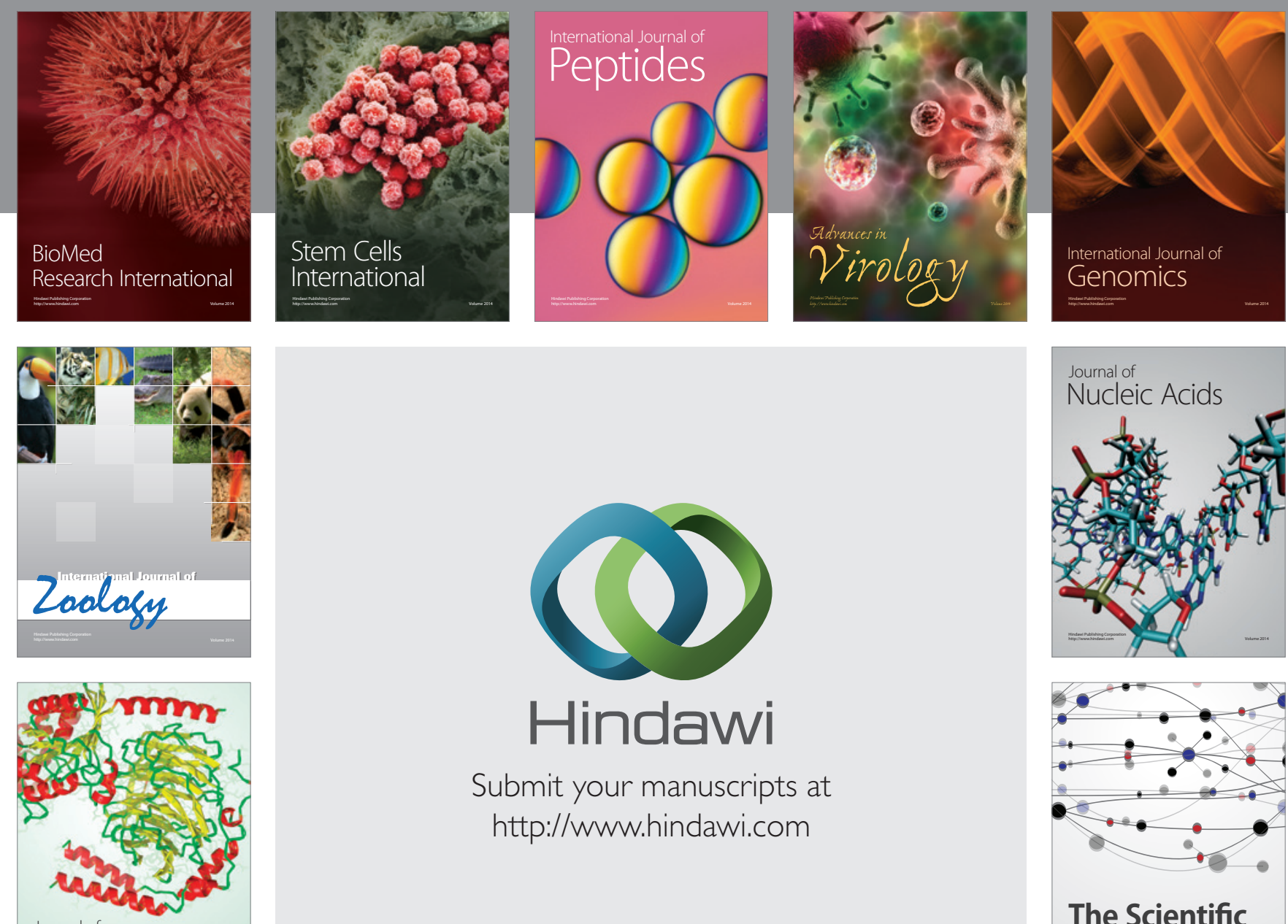

Submit your manuscripts at

http://www.hindawi.com

Journal of
Signal Transduction
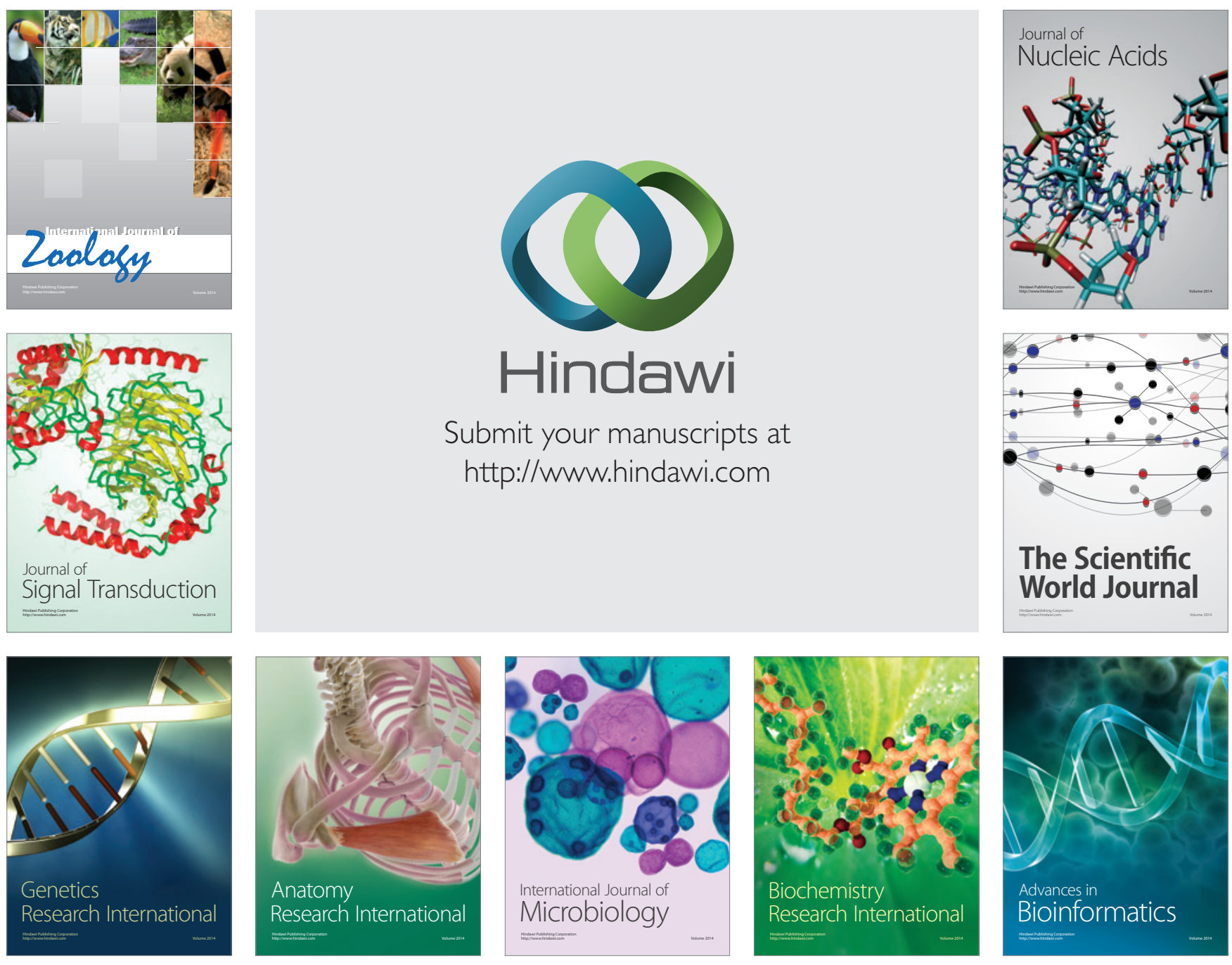

The Scientific World Journal
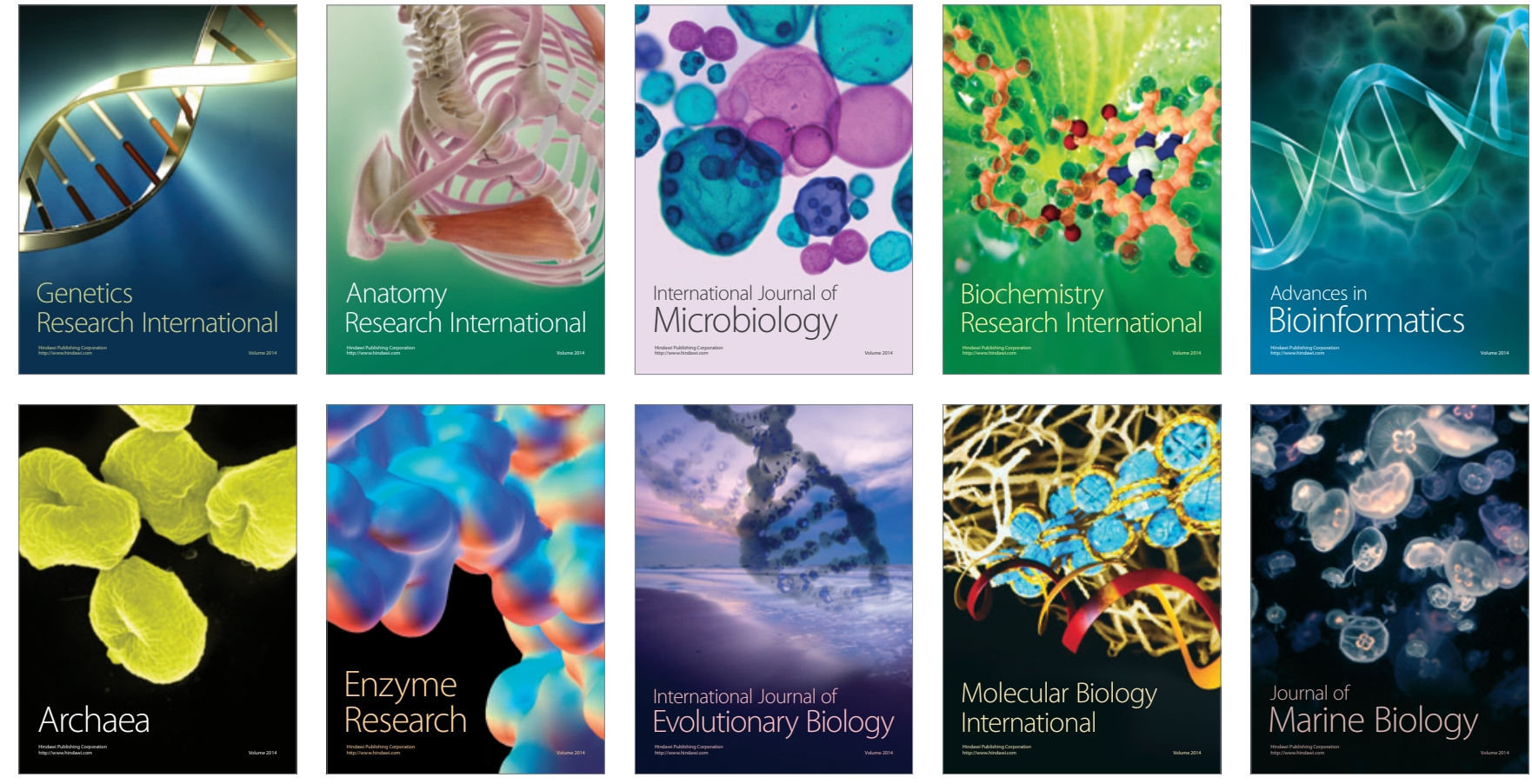